\title{
Cytotoxic T Lymphocyte Responsiveness after Resolution of Chronic Hepatitis B Virus Infection
}

\author{
Barbara Rehermann, ${ }^{\star}$ Daryl Lau, ${ }^{\ddagger}$ Jay H. Hoofnagle, ${ }^{\ddagger}$ and Francis V. Chisari* \\ $*$ Department of Molecular and Experimental Medicine, The Scripps Research Institute, La Jolla, California 92037; and ${ }^{\ddagger}$ Liver Diseases \\ Section, Digestive Diseases Branch, National Institute of Diabetes and Digestive and Kidney Diseases, National Institutes of Health, \\ Bethesda, Maryland 20892
}

\begin{abstract}
Clearance of the hepatitis B virus (HBV) during acute hepatitis is associated with a strong, polyclonal, multispecific cytotoxic T lymphocyte (CTL) response to the viral envelope, nucleocapsid and polymerase proteins that persists for decades after clinical recovery. In contrast, chronically infected patients usually fail to mount a strong CTL response to this virus. In this study we demonstrate that chronically infected patients who experience a spontaneous or interferon-induced remission develop a CTL response to $\mathrm{HBV}$ that is similar in strength and specificity to patients who have recovered from acute hepatitis. The results suggest that specific immunotherapeutic enhancement of the CTL response to $\mathrm{HBV}$ should be possible in chronically infected patients, and that it could lead to viral clearance in these individuals with resolution of chronic liver disease. (J. Clin. Invest. 1996. 97:1655-1665.) Key words: HBV • CTL・ interferon • HLA-A2 • limiting dilution analysis
\end{abstract}

\section{Introduction}

The hepatitis $\mathrm{B}$ virus $(\mathrm{HBV})^{1}$ is a noncytopathic DNA virus that causes acute and chronic hepatitis and hepatocellular carcinoma (1). Patients who successfully clear acute HBV infection characteristically mount a strong, polyclonal and multispecific cytotoxic T lymphocyte (CTL) response to HBV (2-6) that lasts for decades following recovery, which is probably maintained by traces of virus that persist indefinitely after clinical and serological recovery (Rehermann, B., C. Ferrari, and F. V. Chisari, manuscript submitted for publication). Approximately $5 \%$ of adults and $95 \%$ of neonates who become infected by HBV develop persistent HBV infection (7), which now affects more than 300 million people worldwide (8). HBV-specific CTL are usually not detectable in the peripheral

Address correspondence to Francis V. Chisari, M.D., Department of Molecular and Experimental Medicine, SBR-10, The Scripps Research Institute, 10666 North Torrey Pines Road, La Jolla, California 92037. Phone: 619-554-8228; FAX: 619-554-6134; E-mail: fchisari@ scripps.edu

Received for publication 25 October 1995 and accepted in revised form 28 December 1995.

1. Abbreviations used in this paper: CRI, CTL response index; CTL, cytotoxic T lymphocyte; $\mathrm{HBcAg}$, hepatitis B core antigen; $\mathrm{HBeAg}$, hepatitis $B$ envelope antigen; HBsAg, hepatitis B surface antigen; $\mathrm{HBV}$, hepatitis B virus; I-NR, interferon nonresponders; I-PR, interferon partial responders; rIL-2, recombinant human IL-2; S-CR, spontaneous complete recovery; S-PR, spontaneous partial recovery.

The Journal of Clinical Investigation

Volume 97, Number 7, April 1996, 1655-1665 blood of these patients, but they are detectable at low precursor frequency at the site of inflammation, the liver $(9,10)$. Hence, it appears that HBV-specific CTL could contribute to chronic inflammatory liver disease by destroying some of the infected hepatocytes, but their precursor frequency is probably too low to eliminate all of the infected hepatocytes and mediate viral clearance.

It is noteworthy, however, that $5-10 \%$ of chronically infected patients clear HBV DNA and hepatitis B envelope antigen $(\mathrm{HBeAg})$ spontaneously each year, and this can be followed by clearance of hepatitis B surface antigen (HBsAg) $(11,12)$. Importantly, spontaneous clearance of HBV-DNA and $\mathrm{HBeAg}$ is generally preceded by an exacerbation of liver disease activity (13) and accompanied by increased $\mathrm{CD} 4^{+}$proliferative $\mathrm{T}$ cell responses to $\operatorname{HBV}(13,14)$, suggesting that latent, immune-mediated clearance mechanisms can become spontaneously activated in some individuals. Furthermore, interferon alpha treatment substantially increases the annual rate of $\mathrm{HBeAg}$ and $\mathrm{HBsAg}$ clearance, with the same antecedent flare in disease activity seen during spontaneous clearance episodes (15). These observations support the notion that HBV-specific CTL are present in chronically infected patients but that they are quantitatively or qualitatively ineffective with respect to HBV clearance. Most importantly, they also imply that this defect is reversible, at least in some individuals.

To test this hypothesis, in the current study we analyzed the HBV-specific CTL response in a group of patients who had previously been treated with interferon alpha for chronic HBV infection, some of whom had cleared the virus while others had not. We also studied a group of untreated patients with chronic hepatitis, some of whom had previously experienced a spontaneous remission, and a group of acutely infected patients who served as a positive control. We now report that HBV-specific CTL are readily detectable in the peripheral blood in many patients who successfully terminate chronic hepatitis.

\section{Methods}

Patient population. 26 patients with chronic hepatitis B, 2 with acute hepatitis B, and 12 uninfected healthy control subjects were studied (Table I). All 40 were positive for HLA-A2 by microcytotoxicity assay.

The 26 patients with chronic hepatitis B were classified into five groups (Table II): (a) eight patients who had never been treated with alpha IFN were positive for HBsAg, HBeAg, and HBV-DNA (untreated patients UT 1-8); (b) five patients who received IFN and had a long-term beneficial response having cleared both $\mathrm{HBeAg}$ and $\mathrm{HBsAg}$ (IFN complete responders: I-CR 1-5); (c) five patients who received IFN and had a partial beneficial response having cleared $\mathrm{HBeAg}$ but not HBsAg (IFN partial responders: I-PR 6-10); $(d)$ four patients who received IFN and did not have a sustained response (IFN nonresponders: I-NR 11-14) remaining positive for $\mathrm{HBsAg}$ and $\mathrm{HBeAg}$ or displaying elevated aminotransferases; $(e)$ four patients who had not been treated with alpha IFN but had spontaneously cleared $\mathrm{HBeAg}$ 
HLA

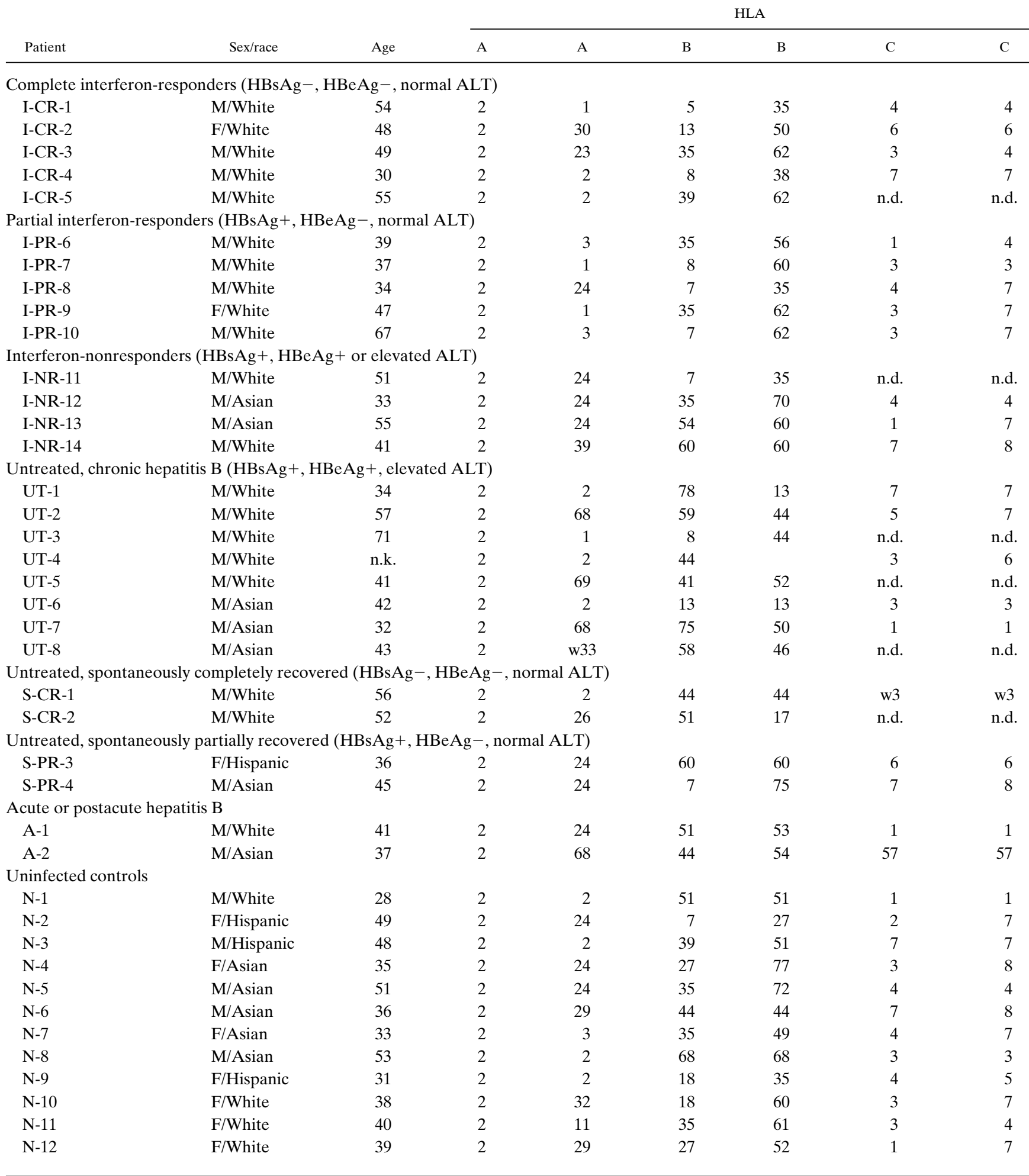

n.d., not done; n.k., not known; ALT, serum alanine aminotransferase.

(spontaneous partial recovery: S-PR 3-4) or both $\mathrm{HBeAg}$ and $\mathrm{HBsAg}$ (spontaneous complete recovery: S-CR 1-2). All except one patient with a complete or partial response or spontaneous recovery had normal serum aminotransferases, and all except one of the untreated or nonresponder patients had raised values.

IFN-treated patients had received therapy as a part of controlled trials of this agent (16-18) except I-NR-14 had been treated 5-11 yr before blood was sampled for this study (Table II). The two patients with acute hepatitis B were positive for HBsAg and $\mathrm{HBeAg}$ and had aminotransferases greater than 10 times the upper limit of the normal range during the acute illness (Table II). Blood for this study was sampled during the acute phase of infection in patient A-1 and during 


\begin{tabular}{|c|c|c|c|c|c|c|c|c|c|c|c|c|c|}
\hline \multirow[b]{3}{*}{ Patient } & \multirow[b]{3}{*}{$\begin{array}{l}\text { Years after } \\
\text { interferon }\end{array}$} & \multirow[b]{3}{*}{$\begin{array}{c}\text { ALT } \\
(\mathrm{U} / \text { liter })^{*}\end{array}$} & \multirow[b]{3}{*}{$\begin{array}{r}\mathrm{HBV}-\mathrm{I} \\
\text { (bDNA) }^{\ddagger}\end{array}$} & \multirow[b]{3}{*}{$\begin{array}{l}\text { NA } \\
(\mathrm{PCR})^{8}\end{array}$} & \multirow[b]{3}{*}{ HBsAg } & \multirow[b]{3}{*}{$\mathrm{HBeAg}$} & \multirow[b]{3}{*}{$\begin{array}{l}\text { anti- } \\
\text { HBs }\end{array}$} & \multirow[b]{3}{*}{$\begin{array}{l}\text { anti- } \\
\text { HBe }\end{array}$} & \multirow[b]{3}{*}{$\begin{array}{l}\text { anti- } \\
\mathrm{HBc}\end{array}$} & \multicolumn{4}{|c|}{ CTL response } \\
\hline & & & & & & & & & & \multirow{2}{*}{$\begin{array}{c}\text { wk } 2 \\
(\mathrm{CRI})\end{array}$} & \multicolumn{3}{|c|}{ wk 3} \\
\hline & & & & & & & & & & & $(>18 \%)$ & $\begin{array}{l}\text { No. peptides } \\
\text { recognized }\end{array}$ & $\begin{array}{c}\text { mean } \\
\% \text { cytotoxicity }\end{array}$ \\
\hline \multicolumn{14}{|c|}{ Complete interferon-responders (HbsAg-, $\mathrm{HBeAg}-$, normal ALT) } \\
\hline I-CR-1 & 11 & 22 & $<0.7$ & $(-)$ & $(-)$ & $(-)$ & $(+)$ & $(+)$ & $(+)$ & 614 & $(+)$ & 3 & 65 \\
\hline I-CR-2 & 7 & 12 & $<0.7$ & $(+)$ & $(-)$ & $(-)$ & $(+)$ & $(+)$ & $(+)$ & 234 & $(+)$ & 2 & 40 \\
\hline I-CR-3 & 8 & 24 & $<0.7$ & $(+)$ & $(-)$ & $(-)$ & $(+)$ & $(+)$ & $(+)$ & 328 & $(+)$ & 2 & 35 \\
\hline I-CR-4 & 7 & 58 & $<0.7$ & $(+)$ & $(-)$ & $(-)$ & $(+)$ & $(+)$ & $(+)$ & 0 & $(+)$ & 1 & 38 \\
\hline I-CR-5 & 5 & 12 & $<0.7$ & $(-)$ & $(-)$ & $(-)$ & $(-)$ & $(-)$ & $(+)$ & 0 & $(+)$ & 1 & 38 \\
\hline \multicolumn{14}{|c|}{ Partial interferon-responders $(\mathrm{HBs} \mathrm{Ag}+, \mathrm{HBe} \mathrm{Ag}-$, normal ALT) } \\
\hline I-PR-6 & 6 & 28 & $<0.7$ & $(-)$ & $(+)$ & $(-)$ & $(-)$ & $(+)$ & $(+)$ & 0 & $(+)$ & 2 & 85 \\
\hline I-PR-7 & 10 & 31 & $<0.7$ & $(+)$ & $(+)$ & $(-)$ & $(-)$ & $(+)$ & $(+)$ & 397 & $(+)$ & 2 & 54 \\
\hline I-PR-8 & 5 & 28 & $<0.7$ & $(+)$ & $(+)$ & $(-)$ & $(-)$ & $(+)$ & $(+)$ & 0 & $(+)$ & 2 & 78 \\
\hline I-PR-9 & 5 & 23 & $<0.7$ & $(+)$ & $(+)$ & $(-)$ & $(-)$ & $(+)$ & $(+)$ & 0 & $(+)$ & 2 & 51 \\
\hline I-PR-10 & 5 & 21 & $<0.7$ & $(+)$ & $(+)$ & $(-)$ & $(-)$ & $(+)$ & $(+)$ & 0 & $(-)$ & 0 & 0 \\
\hline \multicolumn{14}{|c|}{ Interferon-nonresponders $(\mathrm{HBs} \mathrm{Ag}+, \mathrm{HBeAg}+$ or elevated $\mathrm{ALT})$} \\
\hline I-NR-11 & 5 & 26 & 12.41 & $(+)$ & $(+)$ & $(+)$ & $(-)$ & $(-)$ & $(+)$ & 0 & $(-)$ & 0 & 0 \\
\hline I-NR-12 & 7 & 56 & $<0.7$ & $(+)$ & $(+)$ & $(-)$ & $(-)$ & $(+)$ & $(+)$ & 0 & $(+)$ & 1 & 30 \\
\hline I-NR-13 & 1 & 147 & $<0.7$ & $(+)$ & $(+)$ & $(-)$ & $(-)$ & $(+)$ & $(+)$ & 0 & $(-)$ & 0 & 0 \\
\hline I-NR-14 & 1 & 50 & 622 & $(+)$ & $(+)$ & $(+)$ & $(-)$ & $(-)$ & $(+)$ & 0 & $(-)$ & 0 & 0 \\
\hline \multicolumn{14}{|c|}{ Untreated, chronic hepatitis $(\mathrm{HBsAg}+, \mathrm{HBeAg}+$, elevated ALT) } \\
\hline UT-1 & - & 85 & 1788 & n.d. & $(+)$ & $(+)$ & $(-)$ & $(-)$ & $(+)$ & 0 & $(+)$ & 1 & 19 \\
\hline UT-2 & - & 20 & 12348 & n.d. & $(+)$ & $(+)$ & $(-)$ & $(-)$ & $(+)$ & 0 & $(+)$ & 2 & 33 \\
\hline UT-3 & - & 123 & 281 & n.d. & $(+)$ & $(+)$ & $(-)$ & $(-)$ & $(+)$ & 0 & $(+)$ & 2 & 27 \\
\hline UT-4 & - & 421 & n.a. & $(+)$ & $(+)$ & $(+)$ & $(-)$ & n.d. & $(+)$ & 0 & $(+)$ & 2 & 46 \\
\hline UT-5 & - & 246 & 1438 & n.d. & $(+)$ & $(+)$ & $(-)$ & $(-)$ & $(+)$ & 0 & $(-)$ & 0 & 0 \\
\hline UT-6 & - & 247 & 981 & n.d. & $(+)$ & $(+)$ & $(-)$ & $(-)$ & $(+)$ & 0 & $(-)$ & 0 & 0 \\
\hline UT-7 & - & 86 & 65 & n.d. & $(+)$ & $(+)$ & $(-)$ & n.d. & $(+)$ & 0 & n.d. & n.a. & n.a. \\
\hline UT-8 & - & 85 & 20 & n.d. & $(+)$ & $(+)$ & $(-)$ & $(+/-)$ & $(+)$ & 0 & $(-)$ & 0 & 0 \\
\hline Untreated, & pontaneous & y complet & ly recover & d (HBsA &,$- \mathrm{HBe}$ & $\mathrm{Ag}-$, no & nal AL & & & & & & \\
\hline S-CR-1 & - & 13 & $<0.7$ & $(-)$ & $(-)$ & $(-)$ & $(+)$ & $(+)$ & $(+)$ & 190 & $(+)$ & 3 & 48 \\
\hline S-CR-2 & - & 18 & $<0.7$ & $(+)$ & $(-)$ & $(-)$ & $(+)$ & $(-)$ & $(+)$ & 0 & n.d. & n.a. & n.a. \\
\hline Untreated, & pontaneou & y partially & recovered & $\mathrm{HBsAg}$ & $\mathrm{HBeAg}$ & - , norm & ALT) & & & & & & \\
\hline S-PR-3 & - & 38 & $<0.7$ & $(+)$ & $(+)$ & $(-)$ & $(-)$ & $(+)$ & $(+)$ & 152 & $(+)$ & 3 & 26 \\
\hline S-PR-4 & - & 36 & $<0.7$ & $(+)$ & $(+)$ & $(-)$ & $(-)$ & $(+)$ & $(+)$ & 291 & $(+)$ & 0 & 0 \\
\hline Acute or $p$ & stacute Hep & atitis B & & & & & & & & & & & \\
\hline A-1 & - & 844 & 0.757 & $(+)$ & $(+)$ & $(+)$ & $(-)$ & $(-)$ & $(+)$ & $1374 * *$ & n.d. & n.a. & n.a. \\
\hline A-2 & - & 19 & n.d. & $(-)$ & $(-)$ & $(-)$ & $(+)$ & n.a. & $(+)$ & 764 & n.d. & n.a. & n.a. \\
\hline Uninfected & controls & & & & & & & & & & & & \\
\hline N-1 & - & n.d. & n.d. & $(-)$ & $(-)$ & n.d. & $(-)$ & n.d. & $(-)$ & 0 & n.d. & n.a. & n.a. \\
\hline $\mathrm{N}-2$ & - & n.d. & n.d. & $(-)$ & $(-)$ & n.d. & $(-)$ & n.d. & $(-)$ & 0 & n.d. & n.a. & n.a. \\
\hline $\mathrm{N}-3$ & - & n.d. & n.d. & $(-)$ & $(-)$ & n.d. & $(-)$ & n.d. & $(-)$ & 0 & n.d. & n.a. & n.a. \\
\hline $\mathrm{N}-4$ & - & n.d. & n.d. & $(-)$ & $(-)$ & n.d. & $(-)$ & n.d. & $(-)$ & 0 & n.d. & n.a. & n.a. \\
\hline $\mathrm{N}-5$ & - & n.d. & n.d. & $(-)$ & $(-)$ & n.d. & $(-)$ & n.d. & $(-)$ & 0 & n.d. & n.a. & n.a. \\
\hline N-6 & - & n.d. & n.d. & $(-)$ & $(-)$ & n.d. & $(-)$ & n.d. & $(-)$ & 0 & n.d. & n.a. & n.a. \\
\hline $\mathrm{N}-7$ & - & n.d. & n.d. & $(-)$ & $(-)$ & n.d. & $(-)$ & n.d. & $(-)$ & 0 & n.d. & n.a. & n.a. \\
\hline $\mathrm{N}-8$ & - & n.d. & n.d. & $(-)$ & $(-)$ & n.d. & $(-)$ & n.d. & $(-)$ & 0 & $(-)$ & 0 & 0 \\
\hline N-9 & - & n.d. & n.d. & $(-)$ & $(-)$ & n.d. & $(-)$ & n.d. & $(-)$ & 0 & $(-)$ & 0 & 0 \\
\hline N-10 & - & n.d. & n.d. & $(-)$ & $(-)$ & n.d. & $(-)$ & n.d. & $(-)$ & 0 & $(-)$ & 0 & 0 \\
\hline N-11 & - & n.d. & n.d. & $(-)$ & $(-)$ & n.d. & $(-)$ & n.d. & $(-)$ & 0 & $(-)$ & 0 & 0 \\
\hline $\mathrm{N}-12$ & - & n.d. & n.d. & $(-)$ & $(-)$ & n.d. & $(-)$ & n.d. & $(-)$ & 0 & $(+)$ & 1 & 35 \\
\hline
\end{tabular}

*ALT, serum alanine aminotransferase, normal range 0-41 U/liter for interferon-treated patients, $0-45 \mathrm{U} /$ liter for all other patients; ${ }^{\ddagger} \times 1,000,000$ genome equiv. $/ \mathrm{ml} ;{ }^{\S} \mathrm{CRI}$ derived from $4 / 5$ peptides; n.d., not done; n.a., not applicable. 
the convalescent phase, i.e., 16 mo after acute hepatitis in patient A-2. At the time of this study, serum alanine aminotransferase was elevated in patient A-1 and within normal range in patient A-2. While patient A-1 displayed high HBV-DNA levels as determined by bDNA analysis, patient A-2 had completely cleared HBV-DNA and was nonreactive even by the more sensitive nested PCR assay (Table II).

The 12 healthy controls were negative for $\mathrm{HBsAg}$, anti-HBs, and HBV-DNA. All subjects were repeatedly anti-hepatitis C virus and anti-HIV negative.

Synthetic peptides and $H B V$ antigens. A panel of peptides representing five previously identified HLA-A2-restricted HBV CTL epitopes $([2,5,6]$ and F.V. Chisari, unpublished results) was used in this study (Table III). The peptides contained free amine $\mathrm{NH}_{2}$ termini and free acid $\mathrm{COOH}$ termini and were synthesized by the Core Laboratory of the Scripps Research Institute, La Jolla, CA, using FMOC Peptide Chemistry on a Gilson Multipeptide Synthesizer. Recombinant (r) hepatitis B core antigen ( $\mathrm{HBcAg}$ ) was obtained from bacterial extracts of Escherichia coli as previously described (19).

Recombinant expression vectors. Recombinant vaccinia virus constructs encoding the large envelope protein (VHBS4, $a d w$ subtype), the HBV polymerase protein ( $\mathrm{Vpol}$, ayw subtype) $(6,20)$, or the HBVcore protein (C-Vac, ayw subtype) (21) were used to induce transient expression of endogenously processed $\mathrm{HBV}$ proteins in human EBV-B cell lines (B-LCL) as previously described (22). Wt-vaccinia virus (21) was used as a control.

Stimulation of PBMC with synthetic peptides. Between 100 and $250 \mathrm{ml}$ of whole blood was drawn from all patients in bags containing $35 \mathrm{ml}$ CPD solution (920 mg sodium citrate, $892 \mathrm{mg}$ dextrose, $105 \mathrm{mg}$ citric acid, $77.7 \mathrm{mg}$ sodium phosphate monobasic) and processed within $24 \mathrm{~h}$. Cryopreserved, instead of freshly isolated, PBMC was used for the analysis of patients UT-1 to UT-5 only.

PBMC from patients and normal donors were separated on Ficoll-Histopaque density gradients (Sigma Chemical Co., St. Louis, $\mathrm{MO}$ ), washed three times in $\mathrm{Ca}^{2+}$-and $\mathrm{Mg}^{3+}$-free PBS (GIBCO Laboratories, Grand Island, NY), resuspended in RPMI 1640 (GIBCO Laboratories), supplemented with L-glutamine $(2 \mathrm{mM})$, penicillin $(50$ $\mathrm{U} / \mathrm{ml})$, streptomycin $(10 \mu \mathrm{g} / \mathrm{ml})$, and $10 \%$ heat-inactivated human $\mathrm{AB}$ serum and plated in 96-well round bottom plates at $0.4 \times 10^{6}$ cells $/ 100 \mu \mathrm{l}$ per well. Synthetic peptides were added at $10 \mu \mathrm{g} / \mathrm{ml}$ to eight replicate cultures per peptide. Recombinant $\mathrm{HBcAg}$ was added at $1 \mu \mathrm{g} / \mathrm{ml}$ as a source of T cell help $(2,5,6)$ in all patients studied. On days 3 and 10, $100 \mu \mathrm{l}$ of RPMI containing 10\% (vol/vol) human AB serum and $10 \mathrm{U} / \mathrm{ml}$ recombinant human IL-2 (rIL-2) (Hoffmann-La Roche, Inc., Nutley, NJ) were added to each well. On day 7 the cultures were transferred into 96-well flat-bottom plates and restimulated with peptide, rIL-2 and $10^{5}$ irradiated (3,000 rad) autologous PBMC feeder cells. Cultures were tested for cytotoxic activity in a split-well CTL-assay on day 14. The remaining cells in each set of eight replicate wells were combined, transferred into a single well of a 24-well plate, and stimulated with peptide, rIL-2, and $10^{6}$ irradiated $(3,000 \mathrm{rad})$ autologous feeder cells in a total vol of $1 \mathrm{ml}$. After addition of $1 \mathrm{ml}$ complete medium with rIL-2 on day 18, these peptidespecific CTL lines were used on days 21-24 to further characterize the CTL response.

\section{Table III. The Epitopes}

\begin{tabular}{cccclc}
\hline $\begin{array}{c}\text { Epitope } \\
\text { number }\end{array}$ & Virus & Protein & $\begin{array}{c}\text { Amino acid } \\
\text { termini }\end{array}$ & $\begin{array}{c}\text { Amino acid } \\
\text { sequence }\end{array}$ & Reference \\
\hline 1 & HBV & Core & $18-27$ & FLPSDFFPSV & 2 \\
2 & HBV & Env & $183-191$ & FLLTRILTI & $*$ \\
3 & HBV & Env & $335-343$ & WLSLLVPFV & 5 \\
4 & HBV & Pol & $455-463$ & GLSRYVARL & 6 \\
5 & HBV & Pol & $575-583$ & FLLSLGIHL & 6
\end{tabular}

*F.V. Chisari, unpublished results.
Cytotoxicity assay. An HLA-A2.1, B7, Cw7-positive EBV-immortalized B cell line (JY), used for the production of target cells, was maintained in RPMI with $10 \%$ (vol/vol) heat-inactivated FCS (GIBCO Laboratories). Target cells were either incubated overnight with synthetic peptides at $10 \mu \mathrm{g} / \mathrm{ml}$ or infected with recombinant vaccinia viruses. Vaccinia-infected targets were prepared by infection of $10^{6} \mathrm{JY}$-cells at an moi of 10 on a rocking plate at room temperature for $1 \mathrm{~h}$ followed by a single wash and overnight incubation at $37^{\circ} \mathrm{C}$. Target cells were labeled with $100 \mu \mathrm{Ci}$ of ${ }^{51} \mathrm{Cr}$ (Amersham Corp., Arlington Heights, IL) for $1 \mathrm{~h}$ and washed four times with HBSS. Cytolytic activity was determined in a standard 4-h split-well ${ }^{51} \mathrm{Cr}$ release assay using U-bottomed 96-well plates with 3,000 targets/well. Stimulated PBMC from patients and normal controls were tested at E/T ratios of 30-50:1 on day 14 and at an E/T ratio of 60:1 on day 21-24 after induction of the culture. For each peptide eight replicate cultures were tested on day 14 . Percent cytotoxicity was determined from the formula: $100 \times[($ experimental release - spontaneous release $) /($ maximum release - spontaneous release)]. Maximum release was determined by lysis of targets with $10 \%$ Triton X-100 (Sigma Chemical Co.). Spontaneous release was $<25 \%$ of maximum release in all experiments. In selected experiments, anti-CD4 and anti-CD8 antibodies purchased from Becton Dickinson Co. (San Jose, CA) were added to the effector cells, and anti-class I (W6/32) and anti-HLA-A2.1 antibody (MA 2.1) (American Type Tissue Collection, Rockville, MD) were added to the target cells at $10 \mu \mathrm{g} / \mathrm{ml}$ for $30 \mathrm{~min}$ before starting the assay.

Limiting dilution analysis of CTL precursor frequency. For quantitative analysis of epitope specific CTL precursors, varying numbers $\left(0.5-4 \times 10^{5}\right)$ of PBMC plus $10^{5}$ irradiated $(3,000 \mathrm{rad})$ autologous PBMC were plated in individual wells of 96-well U-bottom plates in $100 \mu \mathrm{l}$ RPMI 1640 (GIBCO Laboratories) containing $10 \mu \mathrm{g} / \mathrm{ml}$ peptide and $1 \mu \mathrm{g} / \mathrm{ml} \mathrm{recHBcAg}$ and supplemented with L-glutamine (2 $\mathrm{mM})$, penicillin $(50 \mathrm{U} / \mathrm{ml})$, streptomycin $(10 \mu \mathrm{g} / \mathrm{ml})$, and $10 \%$ heatinactivated human $\mathrm{AB}$ serum. 24 replicate cultures were established at each responder cell concentration. Cultures were fed with $10 \mathrm{U} /$ liter rIL- 2 on days 4,7 , and 11 and restimulated with autologous, irradiated $(3,000 \mathrm{rad}) \mathrm{PBMC}$ and $10 \mu \mathrm{g} / \mathrm{ml}$ peptide on day 7 . A split-well CTL-assay was performed on day 14. Cultures were regarded as positive if the specific cytotoxicity was $>2 \mathrm{SD}$ above the mean of the nonspecific cytotoxicity of all cultures and CTL precursor frequency was calculated using the maximum likelihood method as previously described (23).

$H B V$-DNA determination. HBV-DNA was quantitated using the bDNA nucleic acid hybridization assay Quantiplex ${ }^{\mathrm{TM}}$ HBV-DNA Assay (Chiron Corp., Emeryville, CA) according to the manufacturer's instructions. Results were expressed in $10^{6}$ genome equivalents per ml.

For PCR analysis, HBV-DNA was extracted from serum and PBMC as previously described (24). Briefly, $100 \mu \mathrm{l}$ of serum were incubated at $42^{\circ} \mathrm{C}$ for $3 \mathrm{~h}$ with proteinase $\mathrm{K}(50 \mu \mathrm{g} /$ reaction $)$ in $200 \mu \mathrm{l}$ of lysis buffer containing $10 \mathrm{mM}$ Tris- $\mathrm{HCl}, \mathrm{pH} 8.0,10 \mathrm{mM} \mathrm{NaCl}, 1 \mathrm{mM}$ EDTA, pH 8.0, and $0.5 \%$ SDS. DNA was extracted with phenol-chloroform, precipitated with sodium acetate-ethanol, washed with $70 \%$ ethanol, and dissolved in $20 \mu \mathrm{l}$ of TE buffer (10 mM Tris-HCL, $\mathrm{pH}$ 8.0, and $1 \mathrm{ml}$ EDTA, $\mathrm{pH}$ 8.0). $5 \mu \mathrm{l}$ of the DNA sample was used for PCR-amplification.

PBMC, cryopreserved in 80\% FCS, 10\% DMSO, 10\% RPMI, and stored in liquid nitrogen until use, was thawed quickly, washed once in $15 \mathrm{ml} \mathrm{HBSS}$, and incubated in $5 \mathrm{ml}$ lysis buffer containing 50 $\mu \mathrm{g}$ proteinase $\mathrm{K}$ at $37^{\circ} \mathrm{C}$ overnight. The next day, DNA was extracted with phenol-chloroform, precipitated with sodium acetate-ethanol, washed with $70 \%$ ethanol, and dissolved in TE buffer. $0.2 \mu \mathrm{g}$ of the DNA sample was used for PCR-amplification.

$H B V$ DNA detection using a nested PCR. DNA isolated from serum and PBMC was analyzed by PCR using highly conserved diagnostic primer pairs that yielded a PCR product of 441 and $230 \mathrm{bp}$, respectively (HBV246S GAGTCTAGACTCGTGGTGGA and HBV687AS CGAACCACTGAACAAATGGC as external primers and HBV370S 


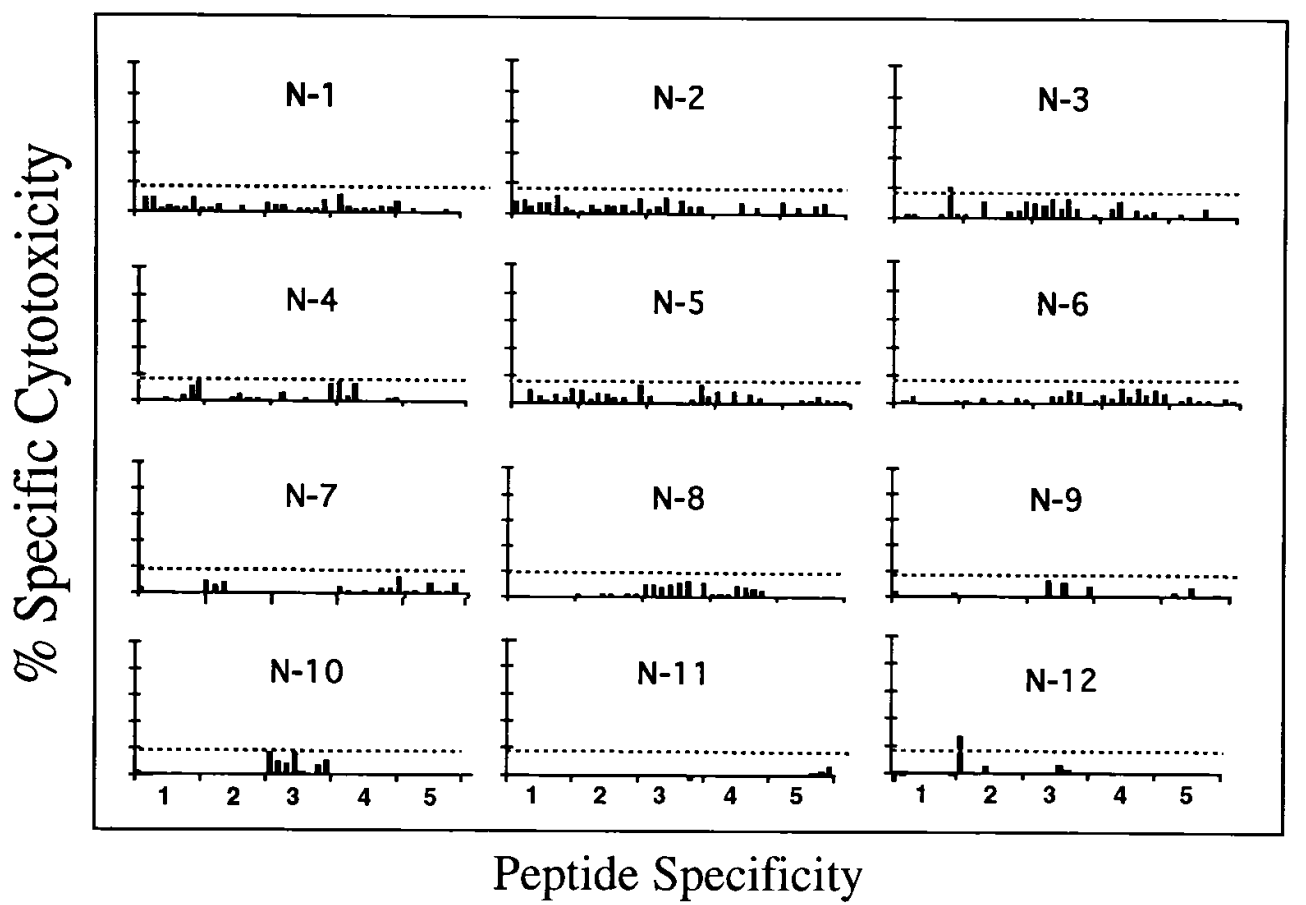

Figure 1. HBV-specific CTL response in healthy, uninfected control persons $(N-1-12)$. PBMC were stimulated with $10 \mu \mathrm{g} / \mathrm{ml}$ of peptide for $2 \mathrm{wk}$ as described in Methods and tested in a $4-\mathrm{h}{ }^{51} \mathrm{Cr}$ release assay against JY target cells prepulsed overnight with the same peptide. Results shown represent percentage of specific lysis in a 4-h ${ }^{51} \mathrm{Cr}$ release assay at an $\mathrm{E} / \mathrm{T}$ ratio of 40-50:1. The peptide specificity is shown in Table III. The dotted line indicates the percent specific cytotoxicity cut-off that was required in at least two of the eight replicate cultures per peptide to reach the definition of a positive CTL response.
TATCGCTGGATGTGTCTGC and HBV660AS CTGAGCCAGGAGAAACGG as internal primers) under the following conditions: 1 cycle of 5 min denaturation at $93^{\circ} \mathrm{C}, 2$ min annealing at $56^{\circ} \mathrm{C}, 3 \mathrm{~min}$ elongation at $72^{\circ} \mathrm{C}$, followed by 35 cycles, in which the denaturation time was decreased to $30 \mathrm{~s}$, the annealing time to $30 \mathrm{~s}$, and the elongation time to $1 \mathrm{~min}$ followed by a 4 min elongation step at $72^{\circ} \mathrm{C}$. For the nested PCR, $10 \mu \mathrm{l}$ of the mixture resulting from the direct reaction was amplified with the internal primer pair under the same conditions.
To eliminate sources of DNA contamination, DNA extraction and PCR were performed in separate rooms, pipetting devices were kept separately, and plugged pipette tips were used. All sera and PBMC samples were divided into small aliquots, and a separate aliquot was used for each analysis. All extractions and amplifications were performed in parallel with relevant negative and positive controls which consisted of DNA derived from the serum and/or PBMC of healthy, uninfected individuals and $\mathrm{HBV}$-positive patients. Con-

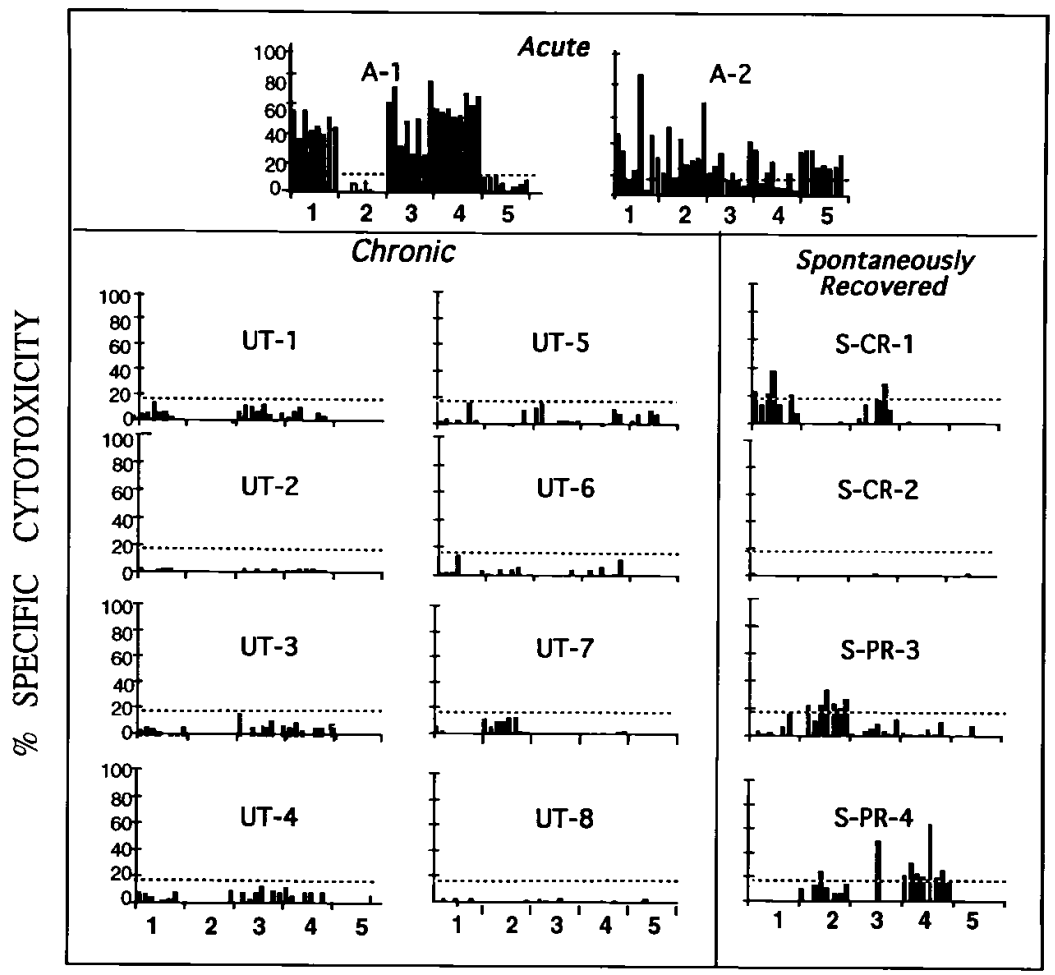

PEPTIDE SPECIFICITY
Figure 2. HBV-specific CTL response in patients with acute HBV one of whom (patients A-1) was currently infected and the other (patient A-2) had resolved the infection 16 mo earlier; eight untreated patients with chronic hepatitis (patients UT-1 to UT-8); and four patients who had completely (patients S-CR-1 and S-CR-2) or partially (patients S-PR-1 and S-PR-2) recovered from chronic hepatitis without antiviral or IFN therapy. PBMC were stimulated with $10 \mu \mathrm{g} / \mathrm{ml}$ of peptide for $2 \mathrm{wk}$ as described in Methods and tested in a $4-\mathrm{h}^{51} \mathrm{Cr}$ release assay against $\mathrm{JY}$ target cells prepulsed overnight with the same peptide. Results shown represent percentage of specific lysis in a 4-h ${ }^{51} \mathrm{Cr}$ release assay at an $\mathrm{E} / \mathrm{T}$ ratio of 40-50:1. The peptide specificity is shown in Table III. The dotted line indicates the percent specific cytotoxicity cutoff required in at least two of the eight replicate cultures to define the CTL response to a given peptide as positive. 
tamination controls consisted of water added to the PCR mixture instead of DNA.

\section{Results}

An $H B V$-specific CTL response is detectable after resolution of chronic hepatitis. Using a macrowell peptide stimulation technique to expand low frequency HBV-specific CTL precursors in the PBMCs of infected patients, we have previously shown that acutely infected patients produce an easily detectable peripheral CTL response to HBV and that chronically infected patients do not (3-6). In the current study we used a miniaturized modification of this technique (Rehermann, B., C. Ferrari, and F. V. Chisari, manuscript submitted for publication) to permit the analysis of multiple replicate assays for each peptide, thereby establishing a database needed to define a "normal range" of irrelevant cytotoxicity. Based on inspection of the responses observed in 12 uninfected normal control subjects using this stimulation technique (Fig. 1), we required at least two of the eight replicate cultures stimulated by a given peptide to display specific cytotoxicity of $>18 \%$ for the CTL response to that peptide to be scored as positive. This level of cytotoxicity was $6 \mathrm{SD}(4 \times 3.8 \%)$ above the mean $(2.3 \%)$ percent cytotoxicity detected for all of the peptide-stimulated cultures in the normal control group (Fig. 1, dashed line).

Using these criteria among two patients with acute hepatitis B (tested during the acute or convalescent phase of disease) vigorous CTL responses were detected in both (Fig. 2). Using the working criteria for a positive CTL response, specific cytotoxicity was present against three of four peptides in patient A-1 and five of five peptides in patient A-2. Furthermore 57 of the 72 individual cultures yielded CTL responses above the cut off of $18 \%$, and in many instances the cytotoxicity was quite high (up to $85 \%$ ). The differential responsiveness of the pa- tients and controls was not due to the use of $\mathrm{HBcAg}$ as a source of $\mathrm{T}$ cell help, since we have previously reported the same selectivity of CTL responsiveness in patients when tetanus toxoid was substituted for $\mathrm{HBcAg}(25)$.

In contrast to patients with acute hepatitis, none of the eight patients with chronic hepatitis B who had not been treated (UT 1-8) achieved the criteria for a positive CTL response, and among 320 individual assays, none were above the cut off of $18 \%$ with this panel of epitopes (Fig. 2). These results using this microcytotoxicity assay system are in accordance with previous reports demonstrating that patients with acute hepatitis B have a multispecific CTL response against HBV whereas patients with chronic hepatitis B have CTL responses that are minimally above background or that of a normal population $(3,5,6,26)$.

In contrast to the chronically infected patients, however, three of the four patients who had previously spontaneously cleared $\mathrm{HBeAg}$ (S-CR-1, S-PR-3, and S-PR-4) displayed a CTL response to at least one of the HBV epitopes studied (Fig. 2), and 20 out of 160 CTL assays were above the cut off of $18 \%$. Similarly, three of the five patients who completely responded to IFN therapy with normalization of serum alanine aminotransferase activity and loss of $\mathrm{HBeAg}$ and $\mathrm{HBsAg}$ (patients I-CR-1, I-CR-2, and I-CR-3) and one of the five partial responders (I-PR-7) also displayed a peripheral blood CTL response against epitopes in the HBV core, envelope, and polymerase proteins (Fig. 3). A total of 47 out of 400 CTL assays was above the cut-off in the group of patients responding to IFN. In contrast, none of the IFN nonresponders displayed a significant response CTL against these HBV epitopes (Fig. 3), and only 1 out of 160 CTL assays was above the cut-off. It is noteworthy that the CTL response was detectable 8-11 yr after IFN therapy in the treated patients even though they had cleared HBV DNA as detected by the branched chain DNA

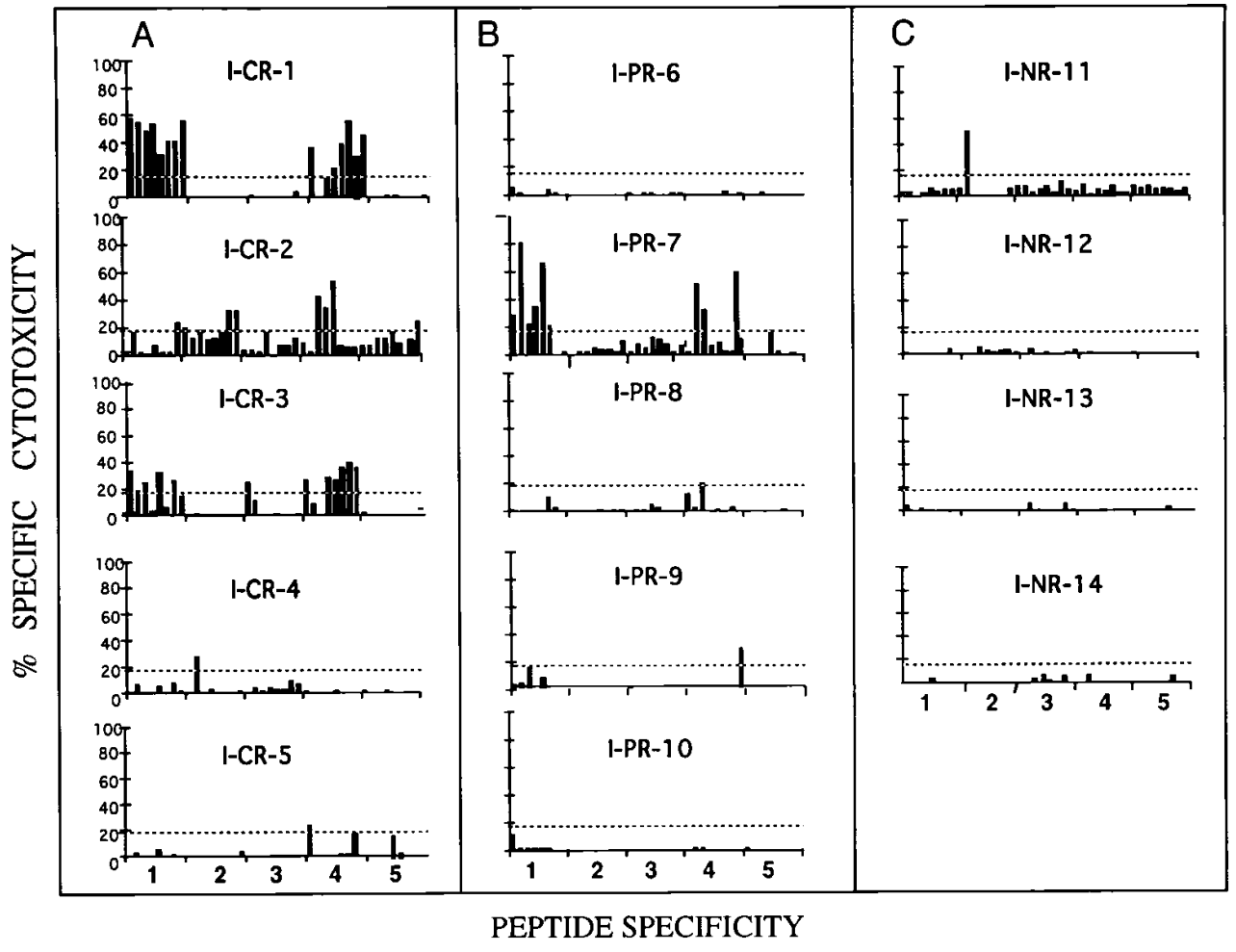

Figure 3. HBV-specific CTL response after 2 wk of in vitro peptide stimulation in chronic HBV patients who responded either completely (patients I-CR-1 to I-CR-5) or partially (patient I-PR-6 to I-PR-10) to IFN therapy. Patients I-NR-11 to I-NR-14 did not respond to IFN. PBMC were stimulated with $10 \mu \mathrm{g} / \mathrm{ml}$ of peptide for $2 \mathrm{wk}$ as described in Methods and tested in a 4-h ${ }^{51} \mathrm{Cr}$ release assay against JY target cells prepulsed overnight with the same peptide. Results shown represent percentage of specific lysis in a $4-\mathrm{h}{ }^{51} \mathrm{Cr}$ release assay at an E/T ratio of 40-50:1. The peptide specificity is shown in Table III. The dotted line indicates the percent specific cytotoxicity cut-off $(18 \%)$ required in at least two of the eight replicate cultures to define the CTL response to a given peptide as positive. 

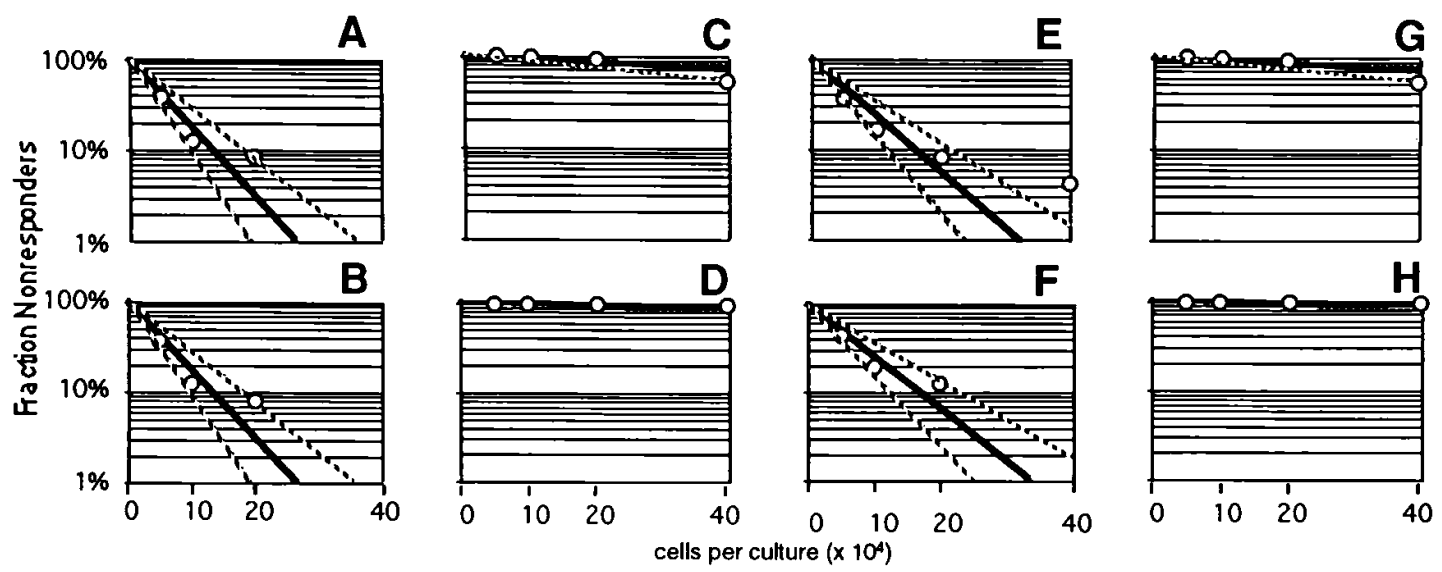

\begin{tabular}{|c|c|c|c|c|c|}
\hline Panel & Patient & Category & Epitope & $\begin{array}{c}\text { CTL } \\
\text { Precursors } \\
\end{array}$ & $\begin{array}{c}95 \% \text { Confidence } \\
\text { Interval }\end{array}$ \\
\hline $\begin{array}{l}\mathbf{A} \\
\mathbf{B}\end{array}$ & $\begin{array}{l}A-1 \\
A-1\end{array}$ & $\begin{array}{l}\text { Acute Hepatitis B } \\
\text { Acute Hepatitis B }\end{array}$ & $\begin{array}{l}\text { Pol455-463 } \\
\text { Env335-343 }\end{array}$ & $\begin{array}{l}1 / 55,000 \\
1 / 69,000\end{array}$ & $\begin{array}{l}1 / 40,000-1 / 75,000 \\
1 / 52,000-1 / 93,000\end{array}$ \\
\hline $\begin{array}{l}\text { C } \\
\text { D }\end{array}$ & $\begin{array}{ll}\text { UT-1 } & \text { u } \\
\text { UT-1 } & \text { u }\end{array}$ & $\begin{array}{l}\text { untreated, chronic hepatitis } \\
\text { untreated, chronic hepatitis }\end{array}$ & $\begin{array}{l}3 \text { Pol455-463 } \\
3 \text { Env335-343 }\end{array}$ & $\begin{array}{c}1 / 708,000 \\
<1 / 5,830,000\end{array}$ & $1 / 460,000-1 / 1,089,000$ \\
\hline $\begin{array}{l}\mathbf{E} \\
\mathbf{F}\end{array}$ & $\begin{array}{l}\text { I-CR-3 } \\
\text { I-CR-3 }\end{array}$ & $\begin{array}{l}\text { Complete IFN-responder } \\
\text { Complete IFN-responder }\end{array}$ & $\begin{array}{l}\text { Pol455-463 } \\
\text { Env335-343 }\end{array}$ & $\begin{array}{l}1 / 70,000 \\
1 / 74,000\end{array}$ & $\begin{array}{c}1 / 52,000-1 / 95,000 \\
1 / 54,000-1 / 102,000\end{array}$ \\
\hline $\mathbf{G}$ & I-PR-8 & Partial IFN-responder & Pol455-463 & $<1 / 909,890$ & * \\
\hline H & I-NR-12 & IFN-Nonresponder & Env335-343 & $<1 / 5,826,429$ & * \\
\hline
\end{tabular}

Figure 4. Analysis of the CTL precursor frequency of selected responses. Peptide specific CTL precursor frequencies were determined after $2 \mathrm{wk}$ of peptide stimulation by limiting dilution analysis as described in Methods. The results are shown as semilogarithmic plot of responder cell input per well against the percentage of negative wells, and also in tabular form. CTL precursors are expressed as number of peptide-specific CTL precursors in $10^{6} \mathrm{PBMC}$. ${ }^{*}$ CTL precursor frequency too low to establish a confidence interval.

assay. Indeed traces of HBV DNA were detectable in either serum or PBMC using the nested PCR technique in most of these individuals (Table II).

The strength of the CTL response is similar after resolution of acute and chronic hepatitis. The strength of the CTL response was estimated semiquantitatively by calculating the CTL response index (CRI) for each patient. The CRI is an arbitrary scoring system that represents the sum of all the specific cytotoxicity percentages greater than the cut off value of $18 \%$ for peptides that scored positive after $2 \mathrm{wk}$ of in vitro stimulation. The CRI provides an estimate of the relative strength of the overall CTL response to the panel of peptides in a given patient. In selected cases, the strength of the CTL response was also quantitated by measuring the CTL precursor frequency displayed by the patient for specific viral peptides. As shown in Table II, the highest CRIs were detected in the two acutely infected patients (CRIs $=1,374$ and 764). The CRI results were intermediate in the four patients with a complete response to IFN (CRIs = 234-614) and were lower among those who had spontaneously cleared HBeAg (CRIs = 152-291).

Thus, it would appear that the CTL response is nearly as strong after clearance of chronic HBV infection as it is after clearance of acute infection. To confirm this impression, the number of $\mathrm{HBV}$-specific CTL precursors in the peripheral blood of representative patients were quantitated by limiting dilution analysis (LDA). As can be seen in Fig. $4 E$ and $F$, pa- tient I-CR-3 displayed CTL precursor frequencies of 1/55,000 and 1/67,000 PBMC for epitopes Env 335-343 and Pol 455-463, respectively. This is comparable to the CTL precursor frequency for the same peptides after resolution of acute hepatitis in patient A-2 (Fig. $4 A$ and $B$ ), and it is 1-2 orders of magnitude higher than in untreated patient UT-16 with chronic hepatitis B (Fig. $4 C$ and $D$ ) and in the IFN nonresponder I-NR-12 (Fig. $4 \mathrm{H}$ ).

Prolonged peptide stimulation unmasks CTL responses in chronically infected patients. The foregoing results (Figs. 1-4) were obtained with PBMC that had been stimulated in vitro with peptides for $2 \mathrm{wk}$. To enhance the sensitivity of the system, the lymphocytes remaining in the microwells after cytotoxicity analysis were pooled, restimulated for a third week with the corresponding peptide, and tested for peptide-specific CTL activity. Using this protocol, most of the CTL responses that could be retested were confirmed and new CTL responses were detected (Figs. 5 and 6 and Table II). Most importantly, CTL responses were detected in three of the untreated patients with ongoing chronic hepatitis that were tested in this manner (Fig. 5) and in almost all of the partial IFN-responders (Fig. 6).

As summarized in Table IV, after 3 wk of in vitro stimulation $15 / 24$ possible CTL responses $(63 \%)$ were detected in the group of patients who completely recovered either spontaneously or after IFN therapy, and 12/35 possible CTL responses 


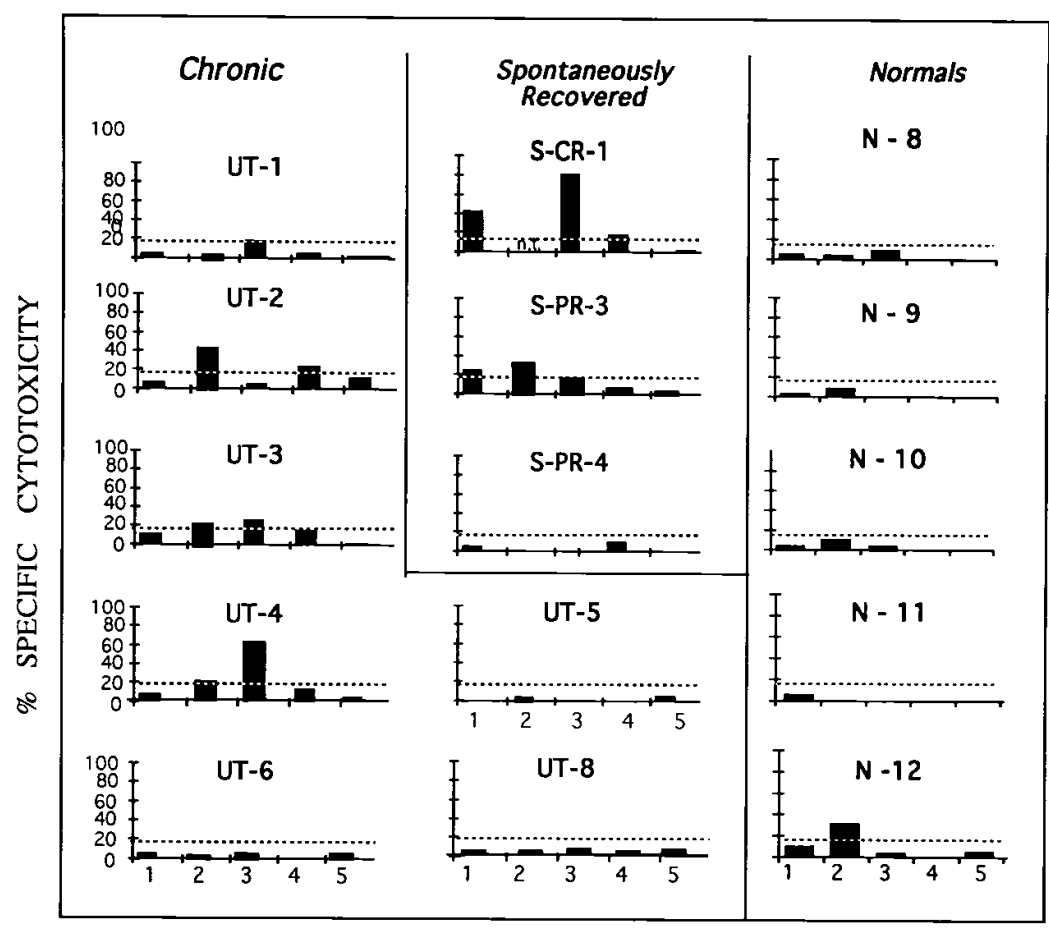

PEPTIDE SPECIFICITY
Figure 5. HBV-specific CTL response after $3 \mathrm{wk}$ of in vitro peptide stimulation. PBMC were stimulated with $10 \mu \mathrm{g} / \mathrm{ml}$ of peptide for $2 \mathrm{wk}$ in eight replicate cultures per peptide, pooled, restimulated on day 14 , and tested in a $4-\mathrm{h}{ }^{51} \mathrm{Cr}$ release assay against $\mathrm{JY}$ target cells prepulsed overnight with the same peptide as described in Methods. Results shown represent percentage of specific lysis in a $4-\mathrm{h}{ }^{51} \mathrm{Cr}$ release assay at an $\mathrm{E} / \mathrm{T}$ ratio of 60:1. The peptide specificity and the dashed line are as described in the legend for Fig. 1 (N-8 to $\mathrm{N}-12$, normal, uninfected controls); the patient groups are as described in the legend to Fig. 2.
(34\%) were observed in the group of patients who recovered partially. Most importantly, 8/40 of the possible responses $(20 \%)$ developed in the untreated patient group. In contrast, only 7 and $4 \%$ (one response per group) of the possible responses were detected in IFN-nonresponders and in the healthy, uninfected control group, respectively, when tested after $3 \mathrm{wk}$ of in vitro stimulation. As shown in Table IV, the same hierarchy was observed when the mean percent cytotoxicity for the peptides that scored as positive was compared in these groups; i.e., it was highest in the complete responders $(47 \pm 19 \%)$ followed by the partial responders $(34 \pm 27 \%)$ and lowest in the untreated patients $(18 \pm 16 \%)$.

This late-developing CTL activity probably reflects a low initial precursor frequency that requires a longer expansion time in vitro to reach detectable levels. The detectability of a CTL response in the untreated patients with chronic hepatitis is compatible with its enhancement after IFN therapy, and it suggests that HBV-specific CTL are present in the peripheral blood during chronic $\mathrm{HBV}$ infection but that their frequency is too low to terminate the infection.

The cytotoxic $T$ cells recognize endogenously processed viral antigens. Peptide-stimulated CTL lines were tested for the ability to recognize endogenously synthesized antigen. Fig. 7 shows representative results of varying the E/T ratio and the type of target cells in CTL assay in two patients with chronic hepatitis B who had a long term complete response. A CTL line from patient I-CR-1 which was specific for Pol 455-463 also recognized endogenously synthesized HBV polymerase antigen. Similarly, a CTL line form patient I-CR-2 specific for the HBVenv 183-191 peptide recognized endogenously synthesized HBsAg. Both peptide-pulsed and vaccinia-infected target cells were lysed efficiently at $\mathrm{E} / \mathrm{T}$ ratios as low as 3.7:1 for patient I-CR-1 and as low as 30:1 for patient I-CR-2 (Fig. 7, $A$ and $B$ ). Control target cells without peptide were not signifi- cantly lysed at these E/T ratios, nor were cells infected by a wild-type vaccinia virus used as control.

The CTL response is Class I and HLA-A2 restricted and mediated by $C D 8$ positive $T$ cells. To further characterize the cell population responsible for the CTL response observed in chronically infected patients that resolved the disease, we blocked the peptide recognition of specific cell lines with a panel of antibodies. As shown in Fig. 7, $C$ and $D$, antigen recognition by the HBcAg 18-27 and HBsAg 335-343 specific CTL lines from patient I-CR-1 and the HBsAg 335-343 specific CTL line from patient I-CR-5 could be efficiently blocked by antibodies targeted against class I or HLA-A2 molecules. Antigen recognition was also significantly inhibited when antibodies against CD8, but not CD4, were incubated with the effector cells before the addition of target cells. These results confirm that the observed CTL response is HLA-A2 restricted and mediated by CD8 positive T cells.

\section{Discussion}

It has been amply demonstrated that patients with acute hepatitis B virus infection produce a strong, polyclonal, and multispecific CTL response to HBV while patients with chronic hepatitis do not $(3,5,6)$. Despite recovery from acute hepatitis, clearance of viral antigens, and appearance of neutralizing antibodies, however, trace amounts of HBV DNA and virusspecific CTL often persist in the blood for decades (24) (Rehermann, B., C. Ferrari, and F. V. Chisari, manuscript submitted for publication) presumably reflecting persistence of a small viral reservoir that actively maintains the CTL response and is controlled by it. In chronically infected patients, however, this balance obviously favors the virus since the peripheral blood CTL response is very weak or not detectable, and the virus persists at titers many orders of magnitude higher than that ob- 


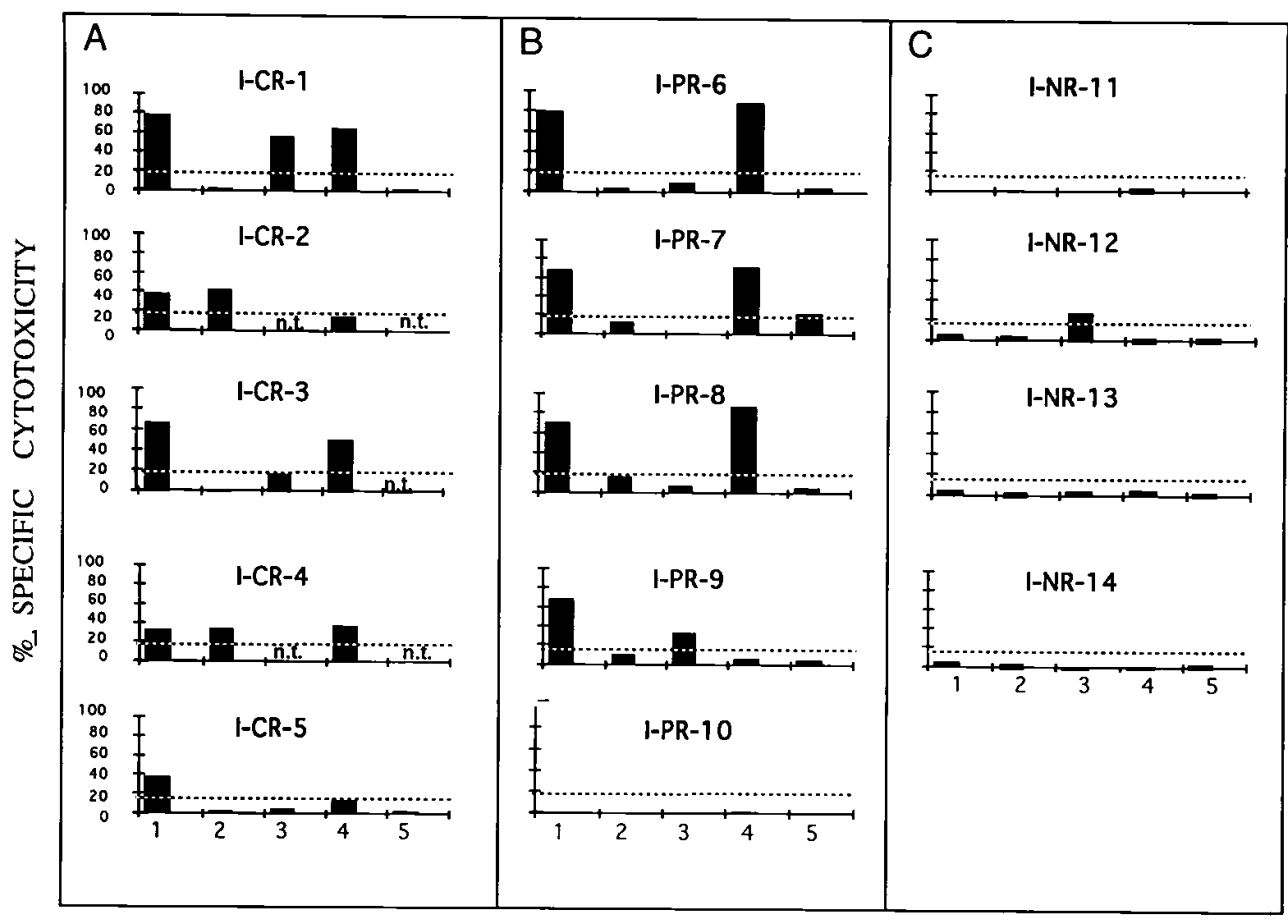

PEPTIDE SPECIFICITY
Figure 6. HBV-specific CTL response after 3 wk of in vitro peptide stimulation. The patient and peptide specificity is as described in the legend for Fig. 2. served after recovery from acute infection $(24,27,28)$. The mechanisms responsible for this imbalance between CTL response and virus that may determine the outcome of infection are not well understood. Elucidation of these mechanisms would contribute to an understanding of the immunological basis for viral persistence during chronic HBV infection and to the development of therapeutic strategies to enhance the $\mathrm{HBV}$-specific immune response in chronically infected patients in the hope of terminating the infection.

The current study demonstrates that CTL specific for at least five epitopes in the HBV nucleocapsid, envelope and polymerase proteins are present in the peripheral blood of patients with chronic hepatitis but that their frequency is low, suggesting that they are quantitatively insufficient to mediate

Table IV. Summary of the Cytotoxic T Cell Response after 3 wk of the Cell Culture

\begin{tabular}{lccc}
\hline \multicolumn{1}{c}{$\begin{array}{c}\text { Patient } \\
\text { group }\end{array}$} & $\begin{array}{c}\text { CTL } \\
\text { responses }\end{array}$ & Mean & SD \\
\cline { 3 - 4 } $\begin{array}{l}\text { Complete responders } \\
\text { (I-CR and S-CR) }\end{array}$ & $15 / 24$ & $47 \%$ & $19 \%$ \\
Partial responders & $63 \%$ & & \\
(I-PR and S-PR) & $12 / 35$ & $34 \%$ & $27 \%$ \\
Untreated patients & $34 \%$ & & \\
(UT) & $8 / 40$ & $18 \%$ & $16 \%$ \\
Nonresponders & $20 \%$ & & \\
(I-NR) & $1 / 15$ & $30 \%$ & - \\
Normal controls & $7 \%$ & & - \\
(N) & $1 / 25$ & $35 \%$ & \\
& $4 \%$ & & \\
\hline
\end{tabular}

viral clearance but probably contribute to the liver disease in these individuals. Most importantly, the data indicate that these CTL can be activated and expanded in vivo in those chronically infected patients who experience spontaneous or IFN-induced viral clearance and disease remission. Furthermore, the CTL response appears to be as strong in these individuals as it is after resolution of acute hepatitis, and to display the same epitope specificity, functional characteristics, and inability to completely eradicate all traces of viral DNA from the blood. Thus, there is reason to believe that specific therapeutic stimulation of the CTL response to HBV may lead to viral clearance and disease remission in patients with chronic hepatitis. The basis for CTL nonresponse in the remaining patients is not clear and deserves further investigation while it is possible.

However, inspection of Table II illustrates several important relationships between the CTL response and clinical, serological, or virological parameters in these patients that could weaken the pathogenetic significance of these observations. For example, all of the patients who displayed a CTL response to $\mathrm{HBV}$ after $2 \mathrm{wk}$ of in vitro stimulation were anti-HBe positive, and most of them were also anti-HBs positive (Table II). While these associations strengthen confidence in the validity of the CTL analysis in these patients, they raise the possibility that the reduction in viral titer in these patients could be due to the combined effects of the CTL and the antibodies, especially the anti-HBs, not just the CTL alone.

Table II also reveals that HBV-specific CTL was detectable (after $2 \mathrm{wk}$ of in vitro stimulation) in $<100 \%$ of the patients who experienced spontaneous or IFN-induced remissions of chronic hepatitis. This raises the possibility that the CTL response may have been secondary to a reduction in viral load rather than causing it. This would be especially germane in the IFN-treated patients where CTL-independent antiviral events could have been initiated by the therapy. Since we did not have the opportunity to examine those patients before and 

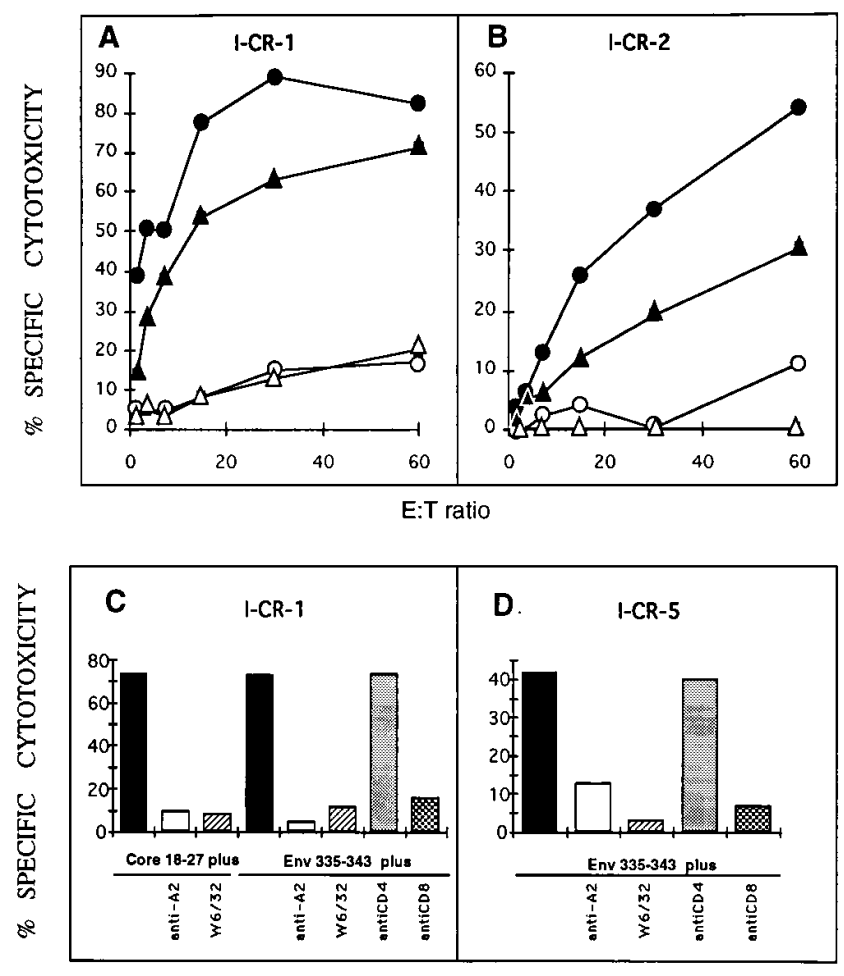

Figure 7. ( $A$ and $B)$ Recognition of endogenously synthesized antigen. Epitope-specific lines were generated by stimulating PBMC from patients I-CR-1 and I-CR-2 with $10 \mu \mathrm{g} / \mathrm{ml}$ of peptide Pol455-463 and $10 \mu \mathrm{g} / \mathrm{ml}$ of peptide Env183-191, respectively as described in Methods. Peptide-specific lines were tested for specific cytotoxicity against JY-target cells either pulsed with $10 \mu \mathrm{g} / \mathrm{ml}$ peptide $(\bullet)$ (Pol455-463 for $A$, Env183-191 for $B$ ) or infected with recombinant vaccinia virus vPol $(A)$ or vHBs4 $(B)$, respectively, $(\boldsymbol{\Lambda})$ in a standard 4-h ${ }^{51} \mathrm{Cr}$ release assay at varying $\mathrm{E} / \mathrm{T}$ ratios. Wild type-vaccinia virus $(\triangle)$ or JY targets without peptide $(O)$ were used as control. ( $C$ and D) Anti-HLA-A2 (MA 2.1) or anti-class I (W6/32) mAbs (American Type Tissue Collection) were added to peptide-pulsed JY target cells and anti-CD4 or anti-CD8 mAbs were added to the corresponding epitope-specific CTL lines at $10 \mu \mathrm{g} / \mathrm{ml} 30 \mathrm{~min}$ before mixing effectors and target cells as described in Methods. Cytotoxicity was measured at an $\mathrm{E} / \mathrm{T}$ ratio of 60:1 in a $4-\mathrm{h}{ }^{51} \mathrm{Cr}$ release assay.

during the course of IFN therapy, we cannot be sure that the CTL response became detectable before the decrease in viral burden and clearance of viral antigens, or whether it appeared afterwards. However, we favor the first option because of a previous report that activation of $\mathrm{HBV}$-specific CD4-positive helper $\mathrm{T}$ cells precedes the resolution of chronic hepatitis $(13,14)$.

Despite these caveats, we believe the current results suggest that the CTL probably contributed to the spontaneous or IFN-induced remissions in these patients for several reasons. First, the strength of the CTL response in these patients was comparable to that observed in patients who had recovered from acute HBV infection in this (Fig. 1) and previous studies (Rehermann, B., C. Ferrari, and F.V. Chisari, manuscript submitted for publication). Second, CTL activity was detectable in virtually all of the patients after an extra week of in vitro stimulation. Third, the strength of these late-onset CTL responses in the patients who experienced remissions was generally stronger than the late-onset CTL responses observed in the untreated patients and the single IFN nonresponder who dis- played a CTL response to a single epitope after $3 \mathrm{wk}$ of in vitro stimulation (Table II).

The results of this study have important implications for the development of immunotherapeutic approaches to terminate $\mathrm{HBV}$ infection in chronically infected patients. The idea that therapeutic enhancement of the HBV-specific CTL response could lead to viral clearance and disease remission in chronic hepatitis is not a new concept (29). Until now, however, this hypothesis has been based on inference from indirect evidence. The current results demonstrating that a strong CTL response commensurate with viral clearance is detectable in patients after resolution of chronic hepatitis establish a factual basis for the foregoing hypothesis. In addition, they raise a cautionary note suggesting that clearance of $\mathrm{HBV}$ and remission of liver disease may require more than enhancement of the CTL response and that the induction of neutralizing antiHBs antibodies may also be needed for viral clearance to occur.

\section{Acknowledgments}

We thank Linda Wilkes (Scripps Clinic and Research Foundation) and Dr. Schindler (Naval Research Medical Center, San Diego, CA) for assistance in recruiting patients.

This study was supported by U. S. Public Health Service grant AI20001 and RR00833 from the National Institutes of Health and a grant from Cytel Corp., San Diego, CA. B. Rehermann was supported by grants Re 1017/1-1 and Re 1017/2-1 from the Deutsche Forschungsgemeinschaft, Bonn, Germany. This is manuscript number 9685-MEM from the Scripps Research Institute.

\section{References}

1. Tiollais, P., C. Pourcel, and A. Dejean. 1985. The hepatitis B virus. Nature (Lond.). 317:489-495.

2. Penna, A., F.V. Chisari, A. Bertoletti, G. Missale, P. Fowler, T. Giuberti, and F. Fiaccadori. 1991. Cytotoxic T lymphocytes recognize an HLA-A2 restricted epitope within the hepatitis B virus nucleocapsid antigen. J. Exp. Med. 174:1565-1570.

3. Missale, G., A. Redeker, J. Person, P. Fowler, S. Guilhot, H.J. Schlicht, C. Ferrari, and F.V. Chisari. 1993. HLA-A31 and Aw68 restricted cytotoxic T cell responses to a single hepatitis B virus nucleocapsid epitope during acute viral hepatitis. J. Exp. Med. 177:751-762.

4. Bertoletti, A., C. Ferrari, F. Fiaccadori, A. Penna, R. Margolskee, H.J. Schlicht, P. Fowler, S. Guilhot, and F.V. Chisari. 1991. HLA class-I restricted human cytotoxic $\mathrm{T}$ cells recognize endogenously synthesized hepatitis $\mathrm{B}$ virus nucleocapsid antigen. Proc. Natl. Acad. Sci. USA. 88:10445-10449.

5. Nayersina, R., P. Fowler, S. Guilhot, G. Missale, A. Cerny, H.-J. Schlicht, A. Vitiello, R. Chesnut, J.L. Person, A.G. Redeker, and F.V. Chisari. 1993. HLA A2 restricted cytotoxic T lymphocyte responses to multiple hepatitis B surface antigen epitopes during hepatitis B virus infection. J. Immunol. 150: 4659-4671.

6. Rehermann, B., P. Fowler, J. Sidney, J. Person, A. Redeker, M. Brown, B. Moss, A. Sette, and F.V. Chisari. 1995. The cytotoxic T lymphocyte response to multiple hepatitis B virus polymerase epitopes during and after acute viral hepatitis. J. Exp. Med. 181:1047-1058.

7. Chisari, F.V., and C. Ferrari. 1996. Immunobiology and pathogenesis of viral hepatitis. In Viral Pathogenesis. N. Nathenson, R. Ahmed, F. GonzalezScarano, D. Griffin, K. Holmes, F.A. Murphy, and H.L. Robinson, editors. Raven Press Ltd., New York. In press.

8. Takano, S., O. Yokosuka, F. Imazeki, M. Tagawa, and M. Omata. 1995. Incidence of hepatocellular carcinoma in chronic hepatitis B and C: a prospective study of 251 patients. Hepatology. 21:650-655.

9. Barnaba, V., A. Franco, A. Balsano, C. Alberti, R. Benvenuto, and F. Balsano. 1989. Recognition of hepatitis B envelope proteins by liver-infiltrating T lymphocytes in chronic HBV infection. J. Immunol. 143:2650-2655.

10. Ferrari, C., A. Penna, T. Giuberti, M.J. Tong, E. Ribera, F. Fiaccadori, and F.V. Chisari. 1987. Intrahepatic, nucleocapsid antigen-specific T cells in chronic active hepatitis B. J. Immunol. 139:2050-2058.

11. Bonino, F., F. Rosina, M. Rizzetto, R. Rizzi, E. Chiaberge, R. Tardanico, F. Callea, and G. Verme. 1986. Chronic hepatitis in HBsAg carriers with serum HBV-DNA and anti-HBe. Gastroenterology. 90:1268-1273.

12. Lohiya, G., S. Lohiya, V.T. Ngo, and R. Crinella. 1986. Epidemiology of 
hepatitis B e antigen and antibody in mentally retarded HBsAg carriers. Hepatology. 6:163-166.

13. Tsai, S.L., M.Y. Chen, M.Y. Lai, P.M. Yang, J.L. Seng, J.H. Huang, L.H. Hwang, T.H. Chang, and D.S. Chen. 1992. Acute exacerbations of chronic type $\mathrm{B}$ hepatitis are accompanied by increased $\mathrm{T}$ cell responses to hepatitis B core and e antigens. J. Clin. Invest. 89:87-96.

14. Jung, M.-C., H.M. Diepolder, U. Spengler, E.A. Wierenga, R. Zachoval, R.M. Hoffmann, D. Eichenlaub, G. Frosner, H. Will, and G.R. Pape. 1995. Activation of a heterogeneous hepatitis B (HB) core and e antigen-specific CD4 ${ }^{+}$ $\mathrm{T}$-cell population during seroconversion to anti-HBe and anti-HBs in hepatitis B virus infection. J. Virol. 69:3358-3368.

15. Alexander, G.J.M., J. Brahm, E.A. Fagan, H.M. Smith, H.M. Daniels, A.L.W.F. Eddleston, and R. Williams. 1987. Loss of HBsAg with interferon therapy in chronic hepatitis B virus infection. Lancet. ii:66-68.

16. Di Bisceglie, A.M., T.-L. Fong, M.W. Fried, G. Swain, B. Baker, J. Korenman, N.V. Bergasa, J.G. Waggoner, Y. Park, and J.H. Hoofnagle. 1993. A randomized controlled trial of recombinant alpha interferon therapy for chronic hepatitis B. Am. J. Gastroent. 88:1887-1892.

17. Hoofnagle, J.H., M.G. Peters, K.D. Mullen, D.B. Jones, V. Rustgi, A. DiBiscegli, C. Hallahan, Y. Park, C. Meschievitz, and E.A. Jones. 1988. Randomized, controlled trial of recombinant human alpha-interferon in patients with chronic hepatitis B. Gastroenterology. 95:1318-1325.

18. Korenman, J., B. Baker, J. Waggoner, J.E. Everhart, A.M. Di Bisceglie, and J.H. Hoofnagle. 1991. Long-term remission of chronic hepatitis B after alpha-interferon therapy. Ann. Intern. Med. 114:629-634.

19. Pasek, M., T. Goto, W. Gilbert, B. Zink, H. Schaller, P. Mackay, G. Leadbetter, and K. Murray. 1979. Hepatitis B virus genes and their expression in E. Coli. Nature (Lond.). 282:575-579.

20. Chakrabarti, S., K. Brechling, and B. Moss. 1985. Vaccinia virus expression vector: coexpression of beta-galactosidase provides visual screening of recombinant plaques. Mol. Cell. Biol. 5:3403-3409.
21. Schlicht, H.J., and H. Schaller. 1989. The secretory core protein of human hepatitis B virus is expressed on the cell surface. J. Virol. 63:5399-5404.

22. Guilhot, S., P. Fowler, G. Portillo, R.F. Margolskee, C. Ferrari, A. Bertoletti, and F.V. Chisari. 1992. Hepatitis B virus (HBV) specific cytolytic T cell response in humans: Production of target cells by stable expression of HBV encoded proteins in immortalized human B cell lines. J. Virol. 66:2670-2678.

23. Fazekas, S., and S. T. Groth. 1982. The evaluation of limiting dilution assays. J. Immunol. Methods. R11:R23.

24. Michalak, T.I., C. Pasquinelli, S. Guilhot, and F.V. Chisari. 1994. Hepatitis B virus persistence after recovery from acute viral hepatitis. J. Clin. Invest. 93:230-239.

25. Cerny, A., P. Fowler, M.A. Brothers, M. Houghton, H.J. Schlicht, and F.V. Chisari. 1995. Induction in vitro of a primary human antiviral cytotoxic T cell response. Eur. J. Immunol. 25:627-630.

26. Nayersina, R., P. Fowler, S. Guilhot, G. Missale, A. Cerny, H.-J. Schlicht, A. Vitiello, R. Chesnut, J. Person, A.G. Redeker, and F.V. Chisari. 1993. HLA A2 restricted cytotoxic $\mathrm{T}$ lymphocyte responses to multiple hepatitis B surface antigen epitopes during hepatitis B virus infection. J. Immunol. 150:4659-4671.

27. Scotto, J., M. Hadchouel, C. Hery, J. Yvart, P. Tiollais, and C. Brechot. 1983. Detection of hepatitis B virus DNA in serum by a simple spot hybridization technique: comparison with results for other viral markers. Hepatology. 3: 279-284.

28. Bonino, F., B. Hoyer, J. Nelson, R. Engle, G. Verme, and J. Gerin. 1981. Hepatitis B virus DNA in the sera of HBsAg carriers: a marker of active hepatitis B virus replication in the liver. Hepatology. 1:386-391.

29. Vitiello, A., G. Ishioka, H.M. Grey, R. Rose, P. Farness, R. LaFond, L. Yuan, F.V. Chisari, J. Furze, R. Bartholomeuz, and R.W. Chesnut. 1995. Development of a lipopeptide-based therapeutic vaccine to treat chronic HBV infection. 1. Induction of a primary cytotoxic $\mathrm{T}$ lymphocyte response in humans. $J$. Clin. Invest. 95:341-349. 